\title{
Brain-Based Learning Teaching Materials to Improve Critical Thinking Skills and Literacy Skills of Students
}

\author{
Lalu Muhamad Ali Zakaria*, Agus Abhi Purwoko \\ Study Program of Science Education \\ Mataram University \\ Mataram, Indonesia \\ *laluzakaria707@gmail.com, agus_ap@unram.ac.id
}

\author{
Saprizal Hadisaputra \\ Study Program of Chemistry Education \\ Mataram University \\ Mataram, Indonesia \\ rizal@unram.ac.id
}

\begin{abstract}
The optimal learning process is able to facilitate learning activities that are in harmony with the workings of the brain. In order for the learning process to take place optimally it is necessary to prepare adequate learning materials; one example is what is known as Brain-Based Learning teaching materials. This study is intended to analyze the effect of Brain-Based Learning teaching materials on critical thinking skills and students' scientific literacy abilities. The analysis was carried out using the Systematic Literature Review (SLR) method, which examined the results of research on the effect of brain-based learning in learning science (biology, physics, and chemistry). Data on critical thinking and scientific literacy were obtained from various journals from the Google Scholar page. The analysis shows that brain-based learning has a positive influence on critical thinking skills and the ability of scientific literacy in the medium category. This article describes the results of a detailed analysis of the relationship between brain-based learning teaching materials and critical thinking skills and students' scientific literacy.
\end{abstract}

Keywords-brain-based learning, teaching materials, critical thinking, scientific literacy

\section{INTRODUCTION}

Learning is a process of interaction between educators, students, and learning materials / resources in a learning activity that can occur outside or in the classroom. In connection with the learning process, the organ that plays a very important role is the brain, which has a unique mechanism of action. For this reason, it is necessary to change learning in harmony with the workings of our brain; one of them is by applying brain-based learning teaching materials.

Science learning (chemistry, physics, and biology) is very closely related to environmental / natural phenomena. In this context environmental phenomena can improve the brain's ability to criticize and increase interest in learning science [1]. As it is understood that learning science aims to develop skills such as: (1) creativity and innovation; (2) communication; (3) collaboration; and (4) critical thinking and problem solving. In science learning students are introduced to facts, concepts, theories, principles, postulates and laws, which are carried out in the form of experiments both inside the laboratory and outside the laboratory [2].

The problems of science learning based on the results of literature studies include: (1) learning is not implementing a strategy that trains 21 st century skills; (2) learning lacks steps that involve the active role of students in practicing critical thinking skills and scientific literacy; (3) The assessment instruments developed are weak in testing the abilities / skills of students as above; and (4) as an impact, critical thinking skills and scientific literacy of students are generally still low.

An interesting question is whether there is a close relationship between critical thinking skills and students' scientific literacy abilities. It has been concluded that the ability to think critically with the ability of scientific literacy has a positive and significant relationship [3]. It was explained that if students are skilled in criticizing phenomena in life related to science learning, the ability of scientific literacy is also high.

One effort to improve students' critical thinking skills and scientific literacy is to apply brain-based learning, which is a learning approach that is in harmony with the workings of the brain [4]. The intended harmonization is needed so that learning is meaningful and fosters long-term memory. Meaningful learning is recognized in the form of a joyful learning process, namely by encouraging active students in learning activities. Science learning emphasizes the way students master concepts and not merely memorize facts [5].

Another report explains that brain-based learning is more effective in improving students' thinking and memory skills compared to lecture learning [6]. Likewise, it turns out that brain-based learning has proven to be effective in improving science process skills and getting to know the environment [7]. 


\section{METHODS}

This study is a meta-analysis of the results of research on brain-based learning models in improving critical thinking skills and scientific literacy. The analysis in question is carried out by the Systematic Literature Review (SLR) method, which was adopted from Triandini [8]. Selected journal articles were obtained from the google scholar page on the topic of BrainBased Learning to enhance critical thinking skills and scientific literacy abilities. Journal review techniques are simplified into three stages, namely planning, conducting, and reporting [9].
The SLR phase is shown in Figure 1. In the first step is the identification of requirements for systematic review (Step 1), namely reviewing the literature on brain-based learning. Then the protocol is designed to direct the implementation of the review and reduce the possibility of researcher bias (Step 2), which is done by defining research questions, search strategies, the process of selecting studies with inclusion and exclusion criteria, quality assessment, and finally data extraction and synthesis processes. The review protocol was developed, evaluated and improved iteratively during the implementation and reporting stages.

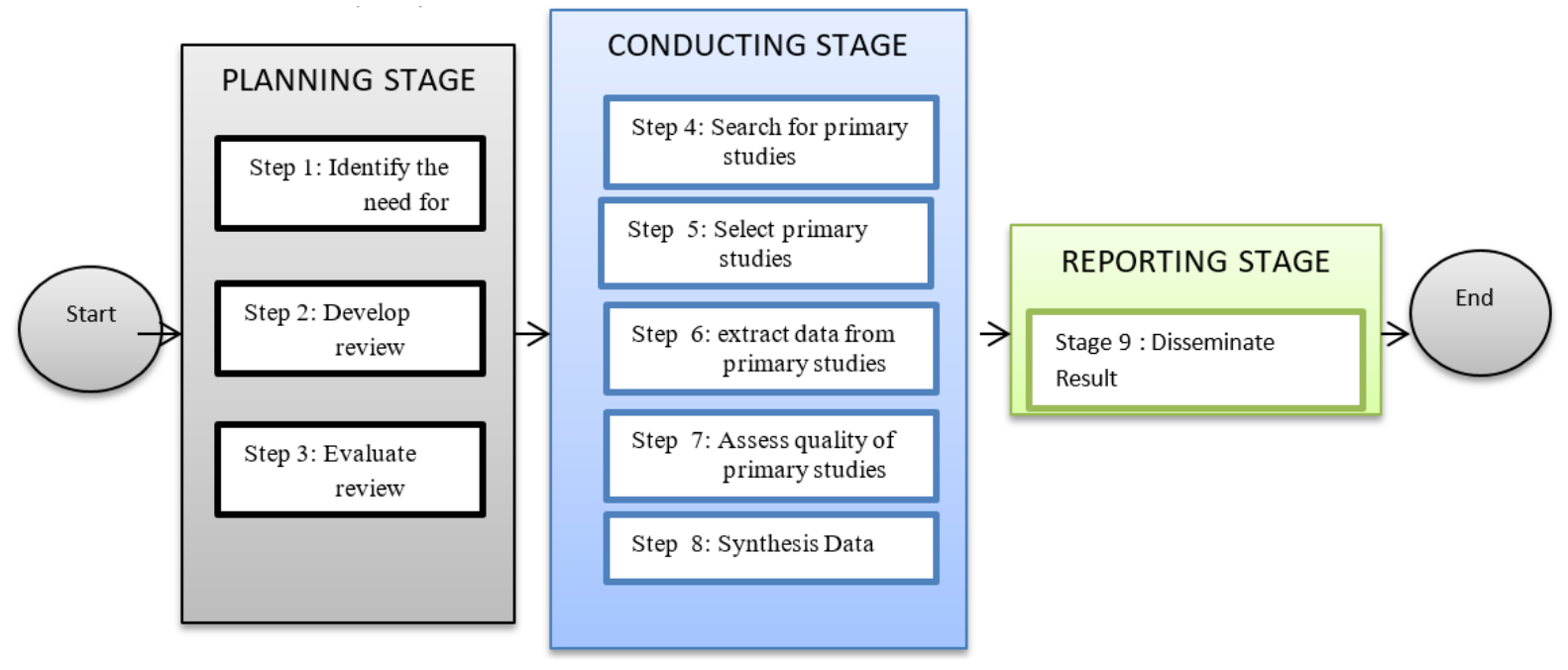

Fig. 1. Systematic Literature Review Steps (adapted from Ref. 8)

The selected review materials are 10 national journal articles and 8 international journal articles indexed by Scopus. The results of the review by the SLR method are outlined in the form of a report, which is then calculated the value of $\mathrm{N}$-gain to determine the increase in critical thinking skills and students' scientific literacy.

The $\mathrm{N}$-gain score obtained from the review results is interpreted with the N-Gain category adopted from Sundayana [10] as table 1 below:
TABLE I. N-GAIN SCORE

\begin{tabular}{|l|l|l|}
\hline No & \multicolumn{1}{|c|}{ Score } & \multicolumn{1}{|c|}{ Category } \\
\hline 1. & $0,00<\mathrm{g}<0,30$ & Low \\
2. & $0,30 \leq \mathrm{g}<0,70$ & Medium \\
3. & $0,70 \leq \mathrm{g} \leq 1,00$ & High \\
\hline
\end{tabular}

\section{RESULTS AND DISCUSSION}

\section{A. Critical Thinking Skills}

Analysis of learning using brain-based learning in improving critical thinking skills can be seen in Table 2 .

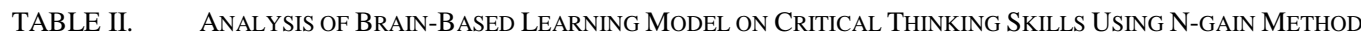

\begin{tabular}{|l|l|l|l|}
\hline \multicolumn{1}{|c|}{ Name of Journal } & Year Published & \multicolumn{1}{c|}{ N-gain Score } & \multicolumn{1}{c|}{ Category } \\
\hline Indonesian Journal of Science and Mathematics Education [11] & 2019 & 0,64 & Medium \\
\hline Journal of Teaching and Learning Physics [12] & 2016 & 0,62 & Medium \\
\hline Jurnal Penelitian Pendidikan IPA [13] & 2018 & 0,58 & Medium \\
\hline Jurnal Penelitian Pendidikan Sains [14] & 2019 & 0,74 & High \\
\hline
\end{tabular}

As shown in Table 2, the application of brain-based learning can improve critical thinking skills, with the majority of $\mathrm{N}$-gains indicating a moderate category. It can be concluded that the application of brain-based learning is able to boost students' skills. Another report also states that learning science with a brain-based learning model or approach makes a significant contribution in improving students' critical thinking skills [15]. 
In addition to the $\mathrm{N}$-gain analysis method the effect of brain-based learning on critical thinking skills is also reported using the anacova analysis method as can be seen in Table 3 below.

TABLE III. ANALYSIS OF BRAIN-BASED LEARNING MODEL ON CRITICAL THINKING SKILLS USING ANCOVA

\begin{tabular}{|l|l|l|l|}
\hline \multicolumn{1}{|c|}{ Name of Journal } & Year Published & F-Value & \multicolumn{1}{c|}{ Category } \\
\hline International Journal of Instruction [16] & 2017 & 0,78 & High \\
\hline American Journal of Educational Research [17] & 2014 & 0,16 & Medium \\
\hline Journal of Turkish Science Education [18] & 2014 & 0,15 & Medium \\
\hline Journal of Education, Society and Behavioural Science [19] & 2018 & 0,92 & High \\
\hline
\end{tabular}

From the results of the meta-analysis it can be concluded that learning that applies brain-based learning has a positive influence on critical thinking skills. The influence exerted was very significant, with an $\mathrm{F}$ value greater than 0.50 .

\section{B. The Scientific Literacy Skills}

The results of brain based learning analysis to improve scientific literacy skills can be seen in Table 4.

TABLE IV. ANALYSIS BRAIN-BASED LEARNING MODEL IN IMPROVING SCIENTIFIC LITERACY SKILLS USING N-GAIN METHOD

\begin{tabular}{|l|l|l|l|}
\hline \multicolumn{1}{|c|}{ Name of Journal } & \multicolumn{1}{|c|}{$\begin{array}{c}\text { Year } \\
\text { Published }\end{array}$} & $\begin{array}{c}\text { N-gain } \\
\text { Score }\end{array}$ & Category \\
\hline Pancaran Pendidikan [20] & 2018 & 0,78 & High \\
\hline $\begin{array}{l}\text { Journal of Science Learning } \\
{[21]}\end{array}$ & 2019 & 0,43 & Low \\
\hline $\begin{array}{l}\text { Journal of Biology Education } \\
\text { [22] }\end{array}$ & 2017 & 0,604 & Medium \\
\hline $\begin{array}{l}\text { Journal of Physics: Conference } \\
\text { Series [23] }\end{array}$ & 2018 & 0,81 & High \\
\hline
\end{tabular}

As shown in Table 4, brain-based learning has a significant positive effect on students' scientific literacy skills, which is characterized by an $\mathrm{N}$-gain score greater than 0.50 or in the moderate category. The results of other studies also concluded that the scientific literacy of students can be improved by using an approach that is able to hone the ability of brain performance, namely the brain-based learning approach [24]. In a somewhat different form the effectiveness of brain-based learning to improve scientific literacy is presented in Table 5 below.

TABLE V. EFFECTIVENESS OF BRAIN-BASED LEARNING TO INCREASE SCIENCE LITERACY

\begin{tabular}{|l|l|l|}
\hline \multicolumn{1}{|c|}{ Name of Journal } & Year Published & Conclusion \\
\hline $\begin{array}{l}\text { Electronic Journal of Science } \\
\text { Education [25] }\end{array}$ & 2017 & Effective \\
\hline $\begin{array}{l}\text { Procedia-Social and Behavioral } \\
\text { Science [26] }\end{array}$ & 2015 & Very effective \\
\hline $\begin{array}{l}\text { International Journal of } \\
\text { Evaluation and Research in } \\
\text { Education [27] }\end{array}$ & 2018 & Effective \\
\hline $\begin{array}{l}\text { Journal of Physics: Conference } \\
\text { Series [28] }\end{array}$ & 2020 & Very effective \\
\hline
\end{tabular}

Various studies shown in Table 5 conclude that learning with a brain-based learning approach is effective in improving the scientific literacy skills of students, especially in learning science. Similar studies also suggest that students' scientific literacy skills can be boosted more effectively by using brainbased learning [29].

\section{Correlation Between Critical Thinking Skills and Science Literacy}

The results of analysis the correlation between critical thinking skills and science literacy in science learning are shown in Table 4.

TABLE VI. CORRELATION BETWEEN CRITICAL THINKING SKILLS AND SCIENCE LITERACY

\begin{tabular}{|l|l|l|l|}
\hline \multicolumn{1}{|c|}{ Title } & \multicolumn{1}{|c|}{$\begin{array}{c}\text { Name of } \\
\text { Journal }\end{array}$} & $\begin{array}{c}\text { Year } \\
\text { Published }\end{array}$ & $\mathbf{R}_{\text {caltd }}$ \\
\hline $\begin{array}{l}\text { Relationship between } \\
\text { Science Literacy and } \\
\text { students critical thinking } \\
\text { skills on chemical bonding } \\
\text { topic }\end{array}$ & $\begin{array}{l}\text { Journal } \\
\text { Education and } \\
\text { Chemistry [30] }\end{array}$ & 2019 & 0,910 \\
\hline $\begin{array}{l}\text { The relationship between } \\
\text { critical thinking skills and } \\
\text { scientific literacy in } \\
\text { integrated science learning } \\
\text { with PBM and STM models }\end{array}$ & $\begin{array}{l}\text { Jurnal Penelitian } \\
\text { Pembelajaran }\end{array}$ & 2016 & 0,463 \\
\hline $\begin{array}{l}\text { Analysis of student crithical } \\
\text { thinking ability in solving } \\
\text { scientific literacy based on } \\
\text { metacognition ability }\end{array}$ & Edusains [32] & & \\
\hline
\end{tabular}

The relationship between critical thinking skills with students' scientific literacy skills shows a positive relationship with a calculated value greater than 0.672 . This large value can be interpreted that the higher the level of students' skills in analyzing a phenomenon on learning, the better the ability of students in the ability of scientific literacy. In another analysis it was concluded that the students' critical thinking skills had a positive influence on the literacy of students [33].

\section{CONCLUSIONS}

From various analyzes of the results of the study above it seems clear that the brain-based learning approach is very suitable to be applied in science learning. This is because critical thinking skills and scientific literacy of students need to be developed through learning, namely the development of life skills that are useful for their future. 


\section{REFERENCES}

[1] E. Ristiyani, and E. S. Bahriah, "Analisis kesulitan belajar kimia siswa di SMAN X Kota Tangerang Selatan," Jurnal Penelitian dan Pembelajaran IPA,vol.2, no.1, 2016.

[2] D. A Putra, K. A. Jasmi, B. Basiron, M. Huda, A. Maseleno, K. Shankar, and N. Aminudin,"Tactical steps for e-government development. International" Journal of pure and applied mathematics, vol . 119, no. $15, .2018$.

[3] G. Rahayuni, "Hubungan keterampilan berpikir kritis dan literasi sains pada pembelajaran IPA terpadu dengan model PBM dan STM," Jurna penelitian dan Pembelajaran IPA, vol. 2, no. 2, 2016.

[4] E. Jensen, Pembelajaran Berbasis Kemampuan Otak : Cara Baru dalam Pengajaran dan Pelatihan (Edisi Revisi). (Terjemahan Narulita Yusron). Thousand Oaks, CA: Corwin Press, 2008.

[5] D. Andrianie, S. Sudarmin, and S. Wardani, "Penerapan Model Pembelajaran Inkuiri Terbimbing Berbantuan Lks Berbasis Representas Kimia Untuk Mereduksi Miskonsepsi Siswa Pada Materi Redoks," Chemistry in Education, vol. 7, no. 2, 2018.

[6] M. Ozden, and M. Gultekin, "The effects of brain based learning on academic achievement and retention of knowledge in science course" EJSE, vol. 12, no.1, 2008

[7] R. Saparina, Pengaruh model brain based learning terhadap hasil belajar biologi siswa kelas X SMA Negeri Colomadu tahun pelajaran 2012/2013, "Journal Bio Pedagogi, vol. 4, no. 1, 2015.

[8] E. Triandini, S. Jayanatha, A. Indrawan, G. W. Putra, and B Iswara, "Metode Systematic Literature Review untuk Identifikasi Platform dan Metode Pengembangan Sistem Informasi di Indonesia", Indonesian Journal of Information Systems, vol.1, no.2,2019

[9] R.S. Wahono, "A Systematic Literature Review of Software Defect Prediction: Research Trends, Datasets, Methods and Frameworks", Journal of Software Engineering, Vol. 1, No. 1, 2015.

[10] R. Sundayana,Statistik Penelitian Pendidikan,Bandung:Alfabeta,2014.

[11] H. Diani, Irwandani, and D. Fujiani, "Physics Learning With brain Based Learning (BBL): Impact on Skills Critical Thinking Schills,' Indonesian Journal of Science and Mathematics Education, vol.2 ,no.5, 2019

[12] U. P. Lestari, A. Malik and D. Mulhayati, Penerapan Model Brain Based Learning untuk Meningkatkan Keterampilan Berpikir Kritis Siswa Materi Usaha dan Energi," Journal of Teaching and Learning Physics, vol. 1 ,no. $2,2016$.

[13] L. D. Herliandry, A. Harjono and J. Ardhuha, "Kemampuan Berpikir Kritis Fisika Peserta Didik Kelas X dengan Model Brain Based Learning,” Jurnal Penelitian Pendidikan IPA, vol.5 ,no.1, 2019.

[14] A. Y. Amanati , Wasis, and M. Ibrahim," The Effectiveness Of Learning Instrument Of Multiple Representations Based Inquiry Model To Train Critical Thinking Skills In Physics Lesson,” Jurnal Penelitian Pendidikan Sains, vol.3 ,no.2, 2019.

[15] E. GöZÜYESiL and A. DiKici, "The Effect of Brain Based Learning on Academic Achievement: A Meta-Analytical Study," Educational Consultancy And Research, vol.14, no. 2, 2014.

[16] N. M. Fuad, S. Zubaidah ,S. Mahanal and E. Suarsini,” Improving Junior High Schools' Critical Thinking Skills Based on Test Three Different Models of Learning”, International Journal of Instruction, vol.10, no.1, 2017.
[17] S. Ramdiah and A. D. Corebima," Learning Strategy Equalizing Students' Achievement, Metacognitive, and Critical Thinking Skills", American Journal of Educational Research,vol. 2, no.8, 2014.

[18] E. DEMIRHAN , İ. ÖNDER, Ş. BEŞOLUK," Brain Based Biology Teaching: Effects on Cognitive and Affective Features and Opinions of Science Teacher Trainees", Journal of TURKISH SCIENCE EDUCATION, vol. 11, no. 3, 2014.

[19] J. U. Gladys, D. G. Stella and G. B. Omobolanle," Effect of brain-based learning model on colleges of education students' retention and attitude in "current electricity" in Taraba state, Nigeria", Journal of Education, Society and Behavioural Science,vol.25, no.2,2018.

[20] E. M. T. Handayani, J. Prihatinand K. Fikri, "The development of collaboration learning talking chips based on brain based learning for the junior high school science in agroecosystem area," Pancaran Pendidikan, vol. 7 no .4, 2018

[21] A. Sani, D. Rochintaniawati, and N. Winarno, "Using Brain-Based Learning to Promote Students' Concept Mastery in Learning Electric Circuit," Journal of Science Learning, vol. 2 no .2, 2019.

[22] A. B. Santoso, S. Alimah, and N. R. Utami, "Biological Science Curriculum Study 5e Instructional Model dengan Pendekatan Jelajah Alam Sekitar terhadap Kemampuan Literasi Sains," Journal of Biology Education, vol. 6 no .2, 2019.

[23] S. E. Atmojo,W. Kurniawati, and T. Muhtarom," Science Learning Integrated Ethnoscienceto Increase Scientific Literacy and Scientific Character", Journal of Physics: Conference Series, 2019.

[24] M. K. Arief and S. Utari, "Implementation of levels of inquiry on science learning to improve junior high school students scientific literacy," Jurnal Pendidikan Fisiska Indonesia, vol. 11, no.2, 2015.

[25] M. Engels, B. Miller, A. Squires, J. S. Jennewein and K. Eitel," The Confluence Approach: Developing scientific literacy through project based learningand place-based education in the context of NGSS", Electronic Journal of Science Education, Vol. 23, No. 3, 2017.

[26] V. Drago and V. Mih, "Scientific Literacy inSchool”, Procedia - Social and Behavioral Sciences, 2015.

[27] Avikasari, Rukayah, and M. Indriayu," The Influence of Science Literacy-Based Teaching MaterialtowardsScience Achievement", nternational Journal of Evaluation and Research in Education, Vol.7, No.3,2018.

[28] P W Hastuti, W Setianingsih and P Anjarsari," How to develop students' scientific literacy through integration of localwisdom in Yogyakarta on science learning?", Journal of Physics: Conference Series, 2020.

[29] I. Ismail, A. Permanasari, and W. Setiawan, "Efektivitas virtual lab berbasis STEM dalam meningkatkan literasi sains siswa dengan perbedaan gender,'. Jurnal Inovasi Pendidikan IPA, vol. 2, no.2, 2016.

[30] Y. Dayelma, Z. Octarya, dan F. Rafelita." Hubungan Literasi Sains dengan keterampilan berpikir kritis siswa pada materi ikatan kimia,' Journal Education and Chemistry, vol. 1, no. 2, 2019

[31] G. Rahayuni," Hubungan keterampilan berpikir kritis dan literasi sain pada pembelajaran IPA terpadu dengan model PBM dan STM,'Jurnal Penelitian dan Pembelajaran IPA, vol. 2 no. 2, 2016.

[32] Z. S. Pamungkas, N. S. Aminah, dan F. Nurosyid," Analysis of studen crithical thinking ability in solving scientific literacy based on metakognition ability,'Edusains, vol. 10, no. 2, 2018.

[33] R. P. Kusumastuti, A. Rusilowati, and S. E. Nugroho, " Pengaruh Keterampilan Berpikir Kritis Terhadap Literasi Sains Siswa,"Unnes Physics Education Journal, vol. 8, no. 3, 2019 